\title{
How common is ponticulus posticus on lateral cephalograms?
}

\author{
Jamal Giri, Prabhat Ranjan Pokharel and Rajesh Gyawali
}

\begin{abstract}
Background: Ponticulus posticus is an anomaly of first cervical vertebra visible on lateral cephalogram and has some serious medical and surgical implications. Unfortunately, it is often overlooked or undetected by orthodontists. The general objective of this study is to sensitize orthodontists about this anomaly by depicting its prevalence among a group of Nepalese orthodontic patients.

Methods: Four hundred and fourteen digital lateral cephalograms of orthodontic patients were retrieved from the archives of the department. The lateral cephalograms were carefully assessed for the presence of ponticulus posticus in the posterior spine of atlas vertebra by two investigators independently and the findings were recorded.

Results: Ponticulus posticus was observed in $35.7 \%$ of the cases, of which $30.9 \%$ had partial ponticulus posticus and 4.8\% had complete ponticulus posticus. Even though there was some female predilection, no statistically significant association was found between gender of the patient and presence of ponticulus posticus.

Conclusion: Ponticulus posticus is a fairly common anomaly with more than one-third (35.7\%) of a group of Nepalese orthodontic patients affected and is independent of gender. Since, this anomaly is associated with numerous medical conditions and has surgical implications, orthodontists should use lateral cephalogram as screening radiograph for this anomaly.
\end{abstract}

Keywords: Cervical vertebra, Lateral cephalogram, Ponticulus posticus

\section{Background}

The importance of lateral cephalogram in orthodontics cannot be overstated. It has been a lynchpin of orthodontic diagnosis and treatment planning since Down introduced the first cephalometric analysis in the late 1940s. The cervical vertebrae visible in the lateral cephalogram are used for assessing the skeletal maturation of growing patients with skeletal discrepancy for growth modification [1]. Apart from that, the cervical vertebrae are not given due attention during routine orthodontic evaluation of lateral cephalograms. Studies have shown that various cervical vertebral anomalies and pathologies can be detected in lateral cephalograms [2-5]. One of such anomalies that can be discerned by watchful eyes is ponticulus posticus.

\footnotetext{
*Correspondence: nepalipilot@gmail.com Department of Orthodontics, College of Dental Surgery, B.P. Koirala Institute of Health Sciences, Dharan, Nepal
}

The ponticulus posticus is a bony bridge in the first cervical vertebra between the lateral mass and the posterior arch. It results due to ossification of the posterior atlanto-occipital ligament of atlas and encloses the vertebral artery and the first cervical nerve root [6]. It has been reported in literature with different names viz; Kimmerle anomaly [7], Atlas bridging [8], Arcuate foramen [9] etc. The clinical significance of this anomaly is somewhat controversial because studies have found a possible association of this cervical spine anomaly with conditions like Migraine, cervicogenic headache and vertigo but there are patients who are asymptomatic despite having ponticulus posticus [10-12]. However, failure to detect ponticulus posticus can have grave complications during cervical spine surgical intervention, especially those requiring screw placement in lateral mass region of Atlas vertebra [13].

Ponticulus posticus has been investigated for over 100 years now using various methods like evaluation of 
vertebrae in cadavers, lateral cephalograms and three dimensional (3D) images. But orthodontic literatures about this anomaly are scarce. It is such an irony given that orthodontists are examining lateral cephalograms everyday with the anomaly just around the corner but is often undetected or overlooked. Orthodontists are not directly involved in the management of migraine or neck pain of patients but as health care professionals it is their responsibility to record any anomaly which could be the etiology of such conditions and refer to the concerned physician if needed. Lateral cephalogram can be a screening radiograph for ponticulus posticus only if orthodontists are familiar with this anomaly of the first cervical vertebra as an old adage goes, "the eyes see what the mind knows".

In the existing literature, a study depicting the prevalence of ponticulus posticus in the Nepalese population is still missing. Hence, the primary objective of the present study is to determine the prevalence of ponticulus posticus among a group of Nepalese orthodontic patients and the secondary objective is to detect any association between the gender of the patient and the presence of this anomaly. This will provide additional population data concerning this anomaly (Additional file 1).

\section{Methods}

Four hundred and fourteen digital lateral cephalograms of the patients presenting for orthodontic treatment were retrieved from the archives of Department of Orthodontics BP Koirala Institute of Health Sciences, Dharan, Nepal. All the radiographs were taken between January 2014 and January 2016. The radiographs of patients with the following characteristics were excluded from the study:

1. Poor display of the posterior arch of the first cervical vertebra due to overlapping of the mastoid process or occiput.

2. Craniofacial syndromes and cleft lip and palate.

3. History of trauma in cervical spine region.

The evaluation of digital radiographs was carried out on a computer screen at $1280 \times 800$ screen resolution. The lateral cephalograms were carefully assessed for the presence of ponticulus posticus in the posterior spine of atlas vertebra by two investigators (JG and RG) independently. Each lateral cephalogram was classified in one of the three ways: absence of ponticulus posticus (Fig. 1), partial ponticulus posticus (Fig. 2) or complete ponticulus posticus (Fig. 3). In case of disagreement between the two investigators a third investigator (PRP) was involved

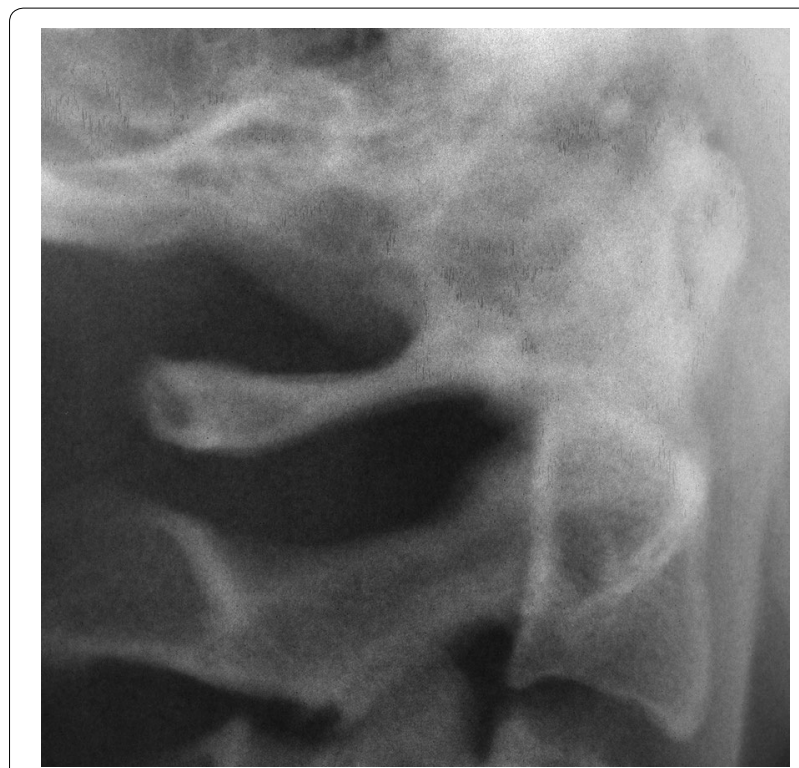

Fig. 1 Cropped image of lateral cephalogram with normal cervical vertebra

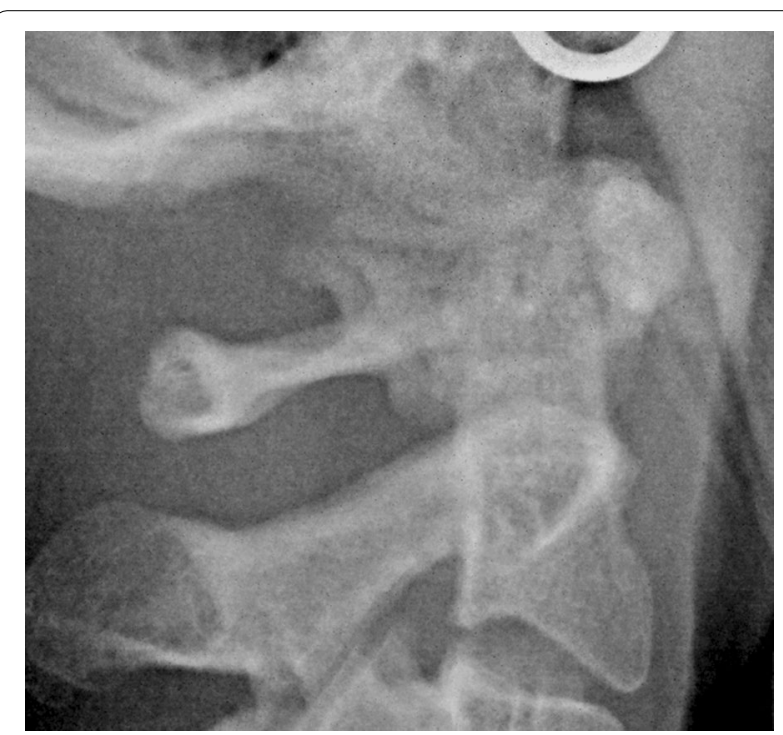

Fig. 2 Cropped image of lateral cephalogram with partial ponticulus posticus

in the decision making process. Final decision was reached on mutual consensus.

SPSS software version 11 was used for data analysis and descriptive statistics were calculated for the samples. Association between the gender of the patient and presence of ponticulus posticus was evaluated using Chi square test with Yates correction. 


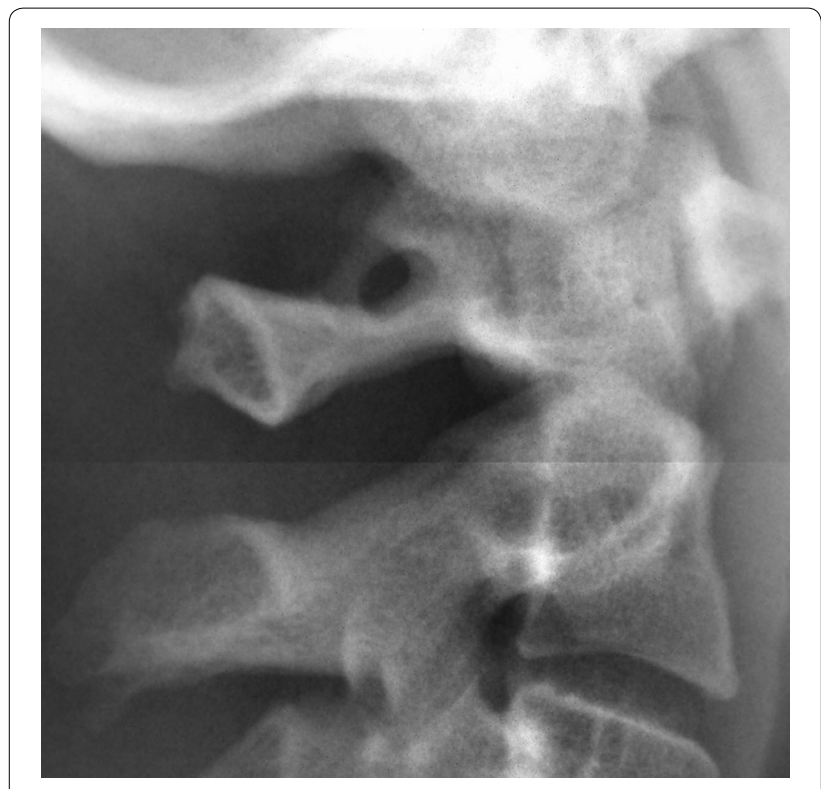

Fig. 3 Cropped image of lateral cephalogram with complete ponticulus posticus

\section{Results}

The mean age of the samples (246 females and 168 males) was $20.59 \pm 4.6$ years with a range of $13-41$ years. Ponticulus posticus was observed in $35.7 \%$ of cases, of which $30.9 \%$ had partial ponticulus posticus and $4.8 \%$ had complete ponticulus posticus.

The data indicate that this anomaly is higher among females compared to males. 79 females $(32.11 \%$ of female sample) had partial ponticulus posticus and complete ponticulus posticus was seen in 15 females (6.09\%). However, males had partial form of this anomaly in 49 samples (29.16\% of male sample) and complete ponticulus posticus in 5 samples (2.9\%) (Table 1$)$. But, this difference was not statistically significant (Table 2).

\section{Discussion}

In this cross sectional study, lateral cephalograms of a group of Nepalese orthodontic patients were evaluated for the presence of ponticulus posticus. The current study found that the prevalence of ponticulus posticus was

Table 1 Distribution of prevalence of ponticulus posticus by gender

\begin{tabular}{lllll}
\hline Gender & \multicolumn{2}{l}{ Ponticulus posticus } & Total \\
\cline { 2 - 4 } & Complete & Partial & Absent & \\
\hline Female & 15 & 79 & 152 & 246 \\
Male & 5 & 49 & 114 & 168 \\
Total & 20 & 128 & 266 & 414 \\
\hline
\end{tabular}

Table 2 Chi square test for association of gender and ponticulus posticus

\begin{tabular}{llll}
\hline & Value & df & $\begin{array}{l}\text { Asymp. Sig. } \\
\text { (2-sided) }\end{array}$ \\
\hline Pearson Chi square & 2.866 & 2 & 0.239 \\
Likelihood ratio & 2.993 & 2 & 0.224 \\
Number of valid cases & 414 & & \\
\hline
\end{tabular}

$35.7 \%$ among a group of Nepalese orthodontic patients with complete ponticulus posticus present in $4.8 \%$ of samples. Similar prevalence were reported in studies conducted in England [14] and Northern Greece [15]. However, a number of studies [16-18] have reported a lower prevalence rate of ponticulus posticus than the present study and there are few studies [19-21] reporting higher prevalence as well. These differences can be attributed to the differences in the ethnicity of the samples around the world.

The other reason for this discrepancy in the prevalence rate could be the method by which this anomaly was assessed. Previous studies had utilized lateral cephalograms [17, 20], cadavers [14, 15], computed tomography (CT) images $[16,22]$ and cone beam computed tomography $(\mathrm{CBCT})$ images $[18,23]$ to assess the prevalence of this anomaly. Moreover, studies have also shown increased accuracy in diagnosis of ponticulus posticus with three dimensional (3D) imaging [16, 24]. However, lateral cephalogram was used in this study for screening ponticulus posticus because it is a routine radiograph for orthodontic patients.

The result of this study showed that even though there was some female predilection, there was no statistically significant association between gender of the patient and presence of ponticulus posticus. This finding is in agreement with those of previous studies [12, 17, 21, 24, 25]. But, few studies have reported male predilection for this anomaly $[6,22]$.

There are conflicting reports regarding the association of chronological age of person and presence of ponticulus posticus. Some studies have suggested that this anomaly is a result of senile ossification and has predilection for older age groups $[15,18,20]$. However, other studies did not find a statistically significant association between the chronological age and the presence of ponticulus posticus $[12,23,26]$. This study could not elucidate the relationship between chronological age and this anomaly owing to a narrow range of chronological age of the samples (13-41 years). Further studies with wider range of chronological age of samples and preferably longitudinal studies will help us understand this relationship.

Studies have shown a possible association between this anomaly and conditions like migraine and chronic 
tension type headache. Some studies have also suggested using ponticulus posticus as one of the major criteria for diagnosis of nevoid basal cell carcinoma syndrome [27, 28]. Furthermore, grave complications await if this anomaly is not identified before lateral mass screw insertion in the first cervical vertebra [13]. Since, ponticulus posticus is fairly common and can be easily detected in lateral cephalograms. Lateral cephalogram should be used as a screening radiograph for this anomaly by orthodontists and if the anomaly is detected it should be documented in patient's health record for future reference.

\section{Conclusion}

Ponticulus posticus is a fairly common anomaly with more than one-third (35.7\%) of a group of Nepalese orthodontic patients affected and is independent of gender. Since, this anomaly is associated with numerous medical conditions and has surgical implications, orthodontists should use lateral cephalogram as a screening radiograph for this anomaly.

\section{Additional file}

Additional file 1. Master-table of data.

\section{Abbreviations}

3D: three-dimensional; CT: computed tomography; CBCT: cone beam computed tomography.

\section{Authors' contributions}

$J G$ research concept and design, selection of radiographs, assessment of radiographs, data analysis and statistics, manuscript preparation, critical revision of the manuscript, final approval of the manuscript. PRP research concept and design, assessment of radiographs, critical revision of the manuscript, final approval of the manuscript. RG research concept and design, selection of radiographs, assessment of radiographs, critical revision of the manuscript, final approval of the manuscript. All authors read and approved the final mansucript.

\section{Acknowledgements}

Not applicable.

\section{Competing interests}

The authors declare that they have no competing interests.

\section{Availability of data and materials}

Master-table of data (Additional file 1) (Excel sheet) has been submitted separately.

\section{Ethics approval and consent to participate}

The study was conducted after obtaining ethical clearance from the institutional review board of BP Koirala Institute of Health Sciences (BPKIHS), Dharan, Nepal (Reference number: Acd.537/072/073) The study used radiographs from the archives of the department of Orthodontics (Secondary data). Hence, patients were not exposed to radiation for study purpose.

\section{Publisher's Note}

Springer Nature remains neutral with regard to jurisdictional claims in published maps and institutional affiliations.
Received: 22 February 2016 Accepted: 25 April 2017

Published online: 28 April 2017

\section{References}

1. Cericato GO, Bittencourt MA, Paranhos LR. Validity of the assessment method of skeletal maturation by cervical vertebrae: a systematic review and meta-analysis. Dento Maxillo Fac Radiol. 2015:44(4):20140270.

2. Tetradis S, Kantor ML. Prevalence of skeletal and dental anomalies and normal variants seen in cephalometric and other radiographs of orthodontic patients. Am J Orthod Dentofacial Orthop. 1999;116(5):572-7.

3. Tetradis S, Kantor ML. Anomalies of the odontoid process discovered as incidental findings on cephalometric radiographs. Am J Orthod Dentofacial Orthop. 2003;124(2):184-9.

4. Soni P, Sharma V, Sengupta J. Cervical vertebrae anomalies-incidental findings on lateral cephalograms. Angle Orthod. 2008;78(1):176-80.

5. Leonardi R, Barbato E, Vichi M, Caltabiano M. Skeletal anomalies and normal variants in patients with palatally displaced canines. Angle Orthod. 2009:79(4):727-32.

6. Pérez I, Chávez A, Ponce D. Frequency of ponticulus posticus in lateral cephalometric radiography of Peruvian patients. Int J Morphol. 2014;32(1):54-60

7. Split W, Sawrasewicz-Rybak M. Character of headache in Kimmerle anomaly. Headache. 2002;42(9):911-6.

8. Manjunath KY. Posterior bridging of the atlas vertebra in south Indians. Indian J Med Sci. 2001;55(9):488-90.

9. Krishnamurthy A, Nayak SR, Khan S, Prabhu LV, Ramanathan LA, Ganesh Kumar C, Prasad Sinha A. Arcuate foramen of atlas: incidence, phylogenetic and clinical significance. Rom J Morphol Embryol. 2007;48(3):263-6.

10. Sabir H, Kumbhare S, Rout P. Evaluation of ponticulus posticus on digital lateral cephalograms and cone beam computed tomography in patients with migraine and healthy individuals: a comparative study. Oral Surg Oral Med Oral Pathol Oral Radiol. 2014;118(3):348-54.

11. Wight S, Osborne N, Breen AC. Incidence of ponticulus posterior of the atlas in migraine and cervicogenic headache. J Manip Physiol Ther. 1999;22(1):15-20.

12. Chen $\mathrm{CH}$, Chen YK, Wang CK. Prevalence of ponticuli posticus among patients referred for dental examinations by cone-beam CT. Spine J. 2015;15(6):1270-6.

13. Elliott RE, Tanweer O. The prevalence of the ponticulus posticus (arcuate foramen) and its importance in the Goel-Harms procedure: meta-analysis and review of the literature. World Neurosurg. 2014;82(1-2):e335-43.

14. Lamberty BG, Zivanovic S. The retro-articular vertebral artery ring of the atlas and its significance. Acta Anat. 1973;85(1):113-22.

15. Paraskevas G, Papaziogas B, Tsonidis C, Kapetanos G. Gross morphology of the bridges over the vertebral artery groove on the atlas. Surg Radiol Anat. 2005;27(2):129-36.

16. Kim KH, Park KW, Manh TH, Yeom JS, Chang BS, Lee CK. Prevalence and Morphologic features of ponticulus posticus in Koreans: analysis of 312 radiographs and 225 three-dimensional CT scans. Asian Spine J. 2007;1(1):27-31.

17. Sharma V, Chaudhary D, Mitra R. Prevalence of ponticulus posticus in Indian orthodontic patients. Dento Maxillo fac Radiol. 2010;39(5):277-83.

18. Bayrakdar IS, Miloglu O, Altun O, Gumussoy I, Durna D, Yilmaz AB. Cone beam computed tomography imaging of ponticulus posticus: prevalence, characteristics, and a review of the literature. Oral Surg Oral Med Oral Pathol Oral Radiol. 2014;118(6):e210-9.

19. Kuhta P, Hart J, Greene-Orndorff L, McDowell-Reizer B, Rush P. The prevalence of posticus ponticus: retrospective analysis of radiographs from a chiropractic health center. J Chiropr Med. 2010;9(4):162-5.

20. Chitroda PK, Katti G, Baba IA, Najmudin M, Ghali SR, Kalmath B. Ponticulus posticus on the posterior arch of atlas, prevalence analysis in symptomatic and asymptomatic patients of gulbarga population. J Clin Diagn Res: JCDR. 2013;7(12):3044-7.

21. Gibelli D, Cappella A, Cerutti E, Spagnoli L, Dolci C, Sforza C. Prevalence of ponticulus posticus in a Northern Italian orthodontic population: a lateral cephalometric study. Surg Radiol Anat. 2015. 
22. Hong JT, Lee SW, Son BC, Sung JH, Yang SH, Kim IS, Park CK. Analysis of anatomical variations of bone and vascular structures around the posterior atlantal arch using three-dimensional computed tomography angiography. J Neurosurg Spine. 2008;8(3):230-6.

23. Geist JR, Geist SM, Lin LM. A cone beam CT investigation of ponticulus posticus and lateralis in children and adolescents. Dento Maxillo Fac Radiol. 2014;43(5):20130451.

24. Cho YJ. Radiological analysis of ponticulus posticus in Koreans. Yonsei Med J. 2009;50(1):45-9.

25. Mudit G, Srinivas K, Satheesha R. Retrospective analysis of ponticulus posticus in Indian orthodontic patients-a lateral cephalometric study. Ethiop J Health Sci. 2014;24(4):285-90.
26. Schilling J, Schilling A, Suazo Gl. Ponticulus posticus on the posterior arch of atlas, prevalence analysis in asymptomatic patients. Int J Morphol. 2010;28(1):317-22.

27. Leonardi R, Santarelli A, Barbato E, Ciavarella D, Bolouri S, Harle F, Palazzo G, Lo Muzio L. Atlanto-occipital ligament calcification: a novel sign in nevoid basal cell carcinoma syndrome. Anticancer Res. 2010;30(10):4265-7.

28. Friedrich RE. Ponticulus posticus is a frequent radiographic finding on lateral cephalograms in nevoid basal cell carcinoma syndrome (Gorlin-Goltz syndrome). Anticancer Res. 2014;34(12):7395-9.

\section{Submit your next manuscript to BioMed Central and we will help you at every step:}

- We accept pre-submission inquiries

- Our selector tool helps you to find the most relevant journal

- We provide round the clock customer support

- Convenient online submission

- Thorough peer review

- Inclusion in PubMed and all major indexing services

- Maximum visibility for your research

Submit your manuscript at www.biomedcentral.com/submit 